\title{
Role of automatic staplers in the aetiology of bronchopleural fistula
}

\author{
MOHSIN HAKIM, BB MILSTEIN \\ From the Department of Cardiothoracic Surgery, Papworth Hospital, Cambridge
}

ABSTRACT The incidence of bronchopleural fistula in 130 patients who had pneumonectomies has been reviewed. Patients were divided into two groups according to the type of automatic stapler used to close the bronchus. From January 1979 to February 1982 the parallel jaw stapler (TA-55) was used in 71 patients (group 1). The new hinged jaw stapler (Premium TA-55) was used in 59 patients from March 1982 to April 1984 (group 2). The incidence of bronchopleural fistula was $4.2 \%$ in group 1 and $15.2 \%$ in group $2(p<0.05)$. The two staplers were tested on a cadaveric bronchial preparation. Radiographs were subsequently taken of the stapled segments. These showed that with the Premium TA-55 closure of staples was not uniform, being incomplete near the hinge unlike the old style TA stapler, which achieves complete and uniform closure of the staples. It is concluded that this undoubtedly contributes to the significantly higher incidence of bronchopleural fistula, and that the new hinged jaw stapler in its present design is not recommended for use during pneumonectomy.

From January 1979 to April 1984 automatic stapling devices were used to close the bronchial stump during 130 pneumonectomies at Papworth Hospital, Cambridge. A parallel jaw stapler (TA-55) was used in the first 71 patients (group 1). Since March 1982 the new hinged jaw stapler (Premium TA-55) has replaced the old type stapler, and has been used for bronchial closure in 59 patients (group 2).

All pneumonectomies were performed for carcinoma, and none of the patients received preoperative radiotherapy. The mean (SD) age was 59.9 (2.3) years for group 1 and $61.7(2.8)$ years for group 2.

Table 1 compares the two groups of patients with respect to sex, side of operation, histological type of growth, and disease of mediastinal nodes. The two groups are comparable, with no statistically significant differences between the two groups.

\section{Instruments and operative method}

\section{THE TWO STAPLES}

In group 1 we used the TA-55 stapler (Autosuture

Address for reprint requests: Mr Mohsin Hakim, Department of Cardiothoracic Surgery, Papworth Hospital, Papworth Everard, Cambridge CB3 8RE.

Accepted 5 September 1984
UK Ltd, 2 Kings Ride Park, Ascot, SL5 8BP, as shown in figure 1). The disposable loading unit consisted of a separate anvil and a staple cartridge. The TA-55 placed a double staggered row of stainless steel staples of leg length $4.8 \mathrm{~mm}$ before closure. After the instrument had been applied around the bronchus, the head of the instrument was approximated to the front jaw in a parallel fashion until the narrow black band on the inner frame was completely within the confines of the wider black band on the outer frame (fig 2).

In group 2 the Premium TA-55 stapler, made by the same manufacturer, was used (fig 3 ). The disposable loading unit consists of an anvil attached to the staple cartridge at a hinge. In the closed position a gap is left between the anvil and cartridge. The instrument is applied to the bronchus as with the TA-55, and the head of the instrument is then approximated to the front jaw in a closing angle.

\section{OPERATION}

A double lumen endobronchial tube was used. The chest was entered through a posterolateral approach. The vessels were either ligated or stapled proximally, ligated distally, and divided. The bronchus was then mobilised up to the carina. The autosuture clamp was applied as close to the origin of the main bronchus as possible. The instrument was then 
Table 1 Details of the two groups*: in group 1 the parallel jaw stapler (TA-55) was used and in group 2 the hinged jaw stapler (Premium TA-55)

\begin{tabular}{|c|c|c|c|c|c|}
\hline & \multicolumn{2}{|c|}{ Group I } & \multicolumn{2}{|c|}{ Group 2} & \\
\hline & No & $\%$ & No & $\%$ & \\
\hline Number of patients & 71 & 100 & 59 & 100 & \\
\hline $\begin{array}{l}\text { Sex } \\
\text { Male } \\
\text { Female }\end{array}$ & $\begin{array}{l}53 \\
18\end{array}$ & $\begin{array}{l}74 \cdot 6 \\
25 \cdot 4\end{array}$ & $\begin{array}{l}47 \\
12\end{array}$ & $\begin{array}{l}79 \cdot 7 \\
20 \cdot 3\end{array}$ & NS \\
\hline $\begin{array}{l}\text { Side } \\
\text { Right } \\
\text { Left }\end{array}$ & $\begin{array}{l}28 \\
43\end{array}$ & $\begin{array}{l}39 \cdot 4 \\
60 \cdot 6\end{array}$ & $\begin{array}{l}19 \\
40\end{array}$ & $\begin{array}{l}32 \cdot 2 \\
67 \cdot 8\end{array}$ & NS \\
\hline $\begin{array}{l}\text { Histological type } \\
\text { Squamous cell carcinoma } \\
\text { Adenocarcinoma } \\
\text { Small cell carcinoma } \\
\text { Large cell carcinoma } \\
\text { Alveolar cell carcinoma } \\
\text { Others }\end{array}$ & $\begin{array}{r}52 \\
9 \\
3 \\
2 \\
1 \\
4\end{array}$ & $\begin{array}{r}73 \cdot 2 \\
12 \cdot 7 \\
4 \cdot 2 \\
2 \cdot 8 \\
1 \cdot 4 \\
5 \cdot 6\end{array}$ & $\begin{array}{r}49 \\
5 \\
2 \\
0 \\
1 \\
2\end{array}$ & $\begin{array}{r}83 \cdot 0 \\
8 \cdot 5 \\
3 \cdot 4 \\
0 \\
1 \cdot 7 \\
3 \cdot 4\end{array}$ & NS \\
\hline $\begin{array}{l}\text { Mediastinal nodes } \\
\text { Positive } \\
\text { Negative }\end{array}$ & $\begin{array}{l}25 \\
46\end{array}$ & $\begin{array}{l}35 \cdot 2 \\
64 \cdot 8\end{array}$ & $\begin{array}{l}18 \\
41\end{array}$ & $\begin{array}{l}30 \cdot 5 \\
69 \cdot 5\end{array}$ & NS \\
\hline
\end{tabular}

${ }^{*}$ There is no significant difference between the groups in any of the features listed according to the $\chi^{2}$ test.

closed and fired to insert the staples, and the bronchus was divided immediately distal to the clamp. The bronchial stump was not covered with pleura or a muscle pedicle. One intercostal drain was inserted and the chest wall closed in layers. Penicillin and flucloxacillin were given for 48 hours, starting with the induction of anaesthesia.

\section{Results}

Of the 130 pneumonectomies, 12 were complicated by bronchopleural fistula, an incidence of $9 \cdot 2 \%$. Three $(4 \cdot 2 \%)$ of these 12 fistulas occurred in group 1 and nine $(15.2 \%)$ in group 2 . All the fistulas occurred within six weeks of the operation. The diagnosis of fistula was made in all patients by observation of a drop in the fluid level in the pneumonectomy space on the chest radiograph. The diagnosis was subsequently confirmed by bronchoscopy in seven patients, at operation in three, and at necropsy in two.

An empyema developed in four cases complicated by fistula, three cases in group 1 and one in group 2 .
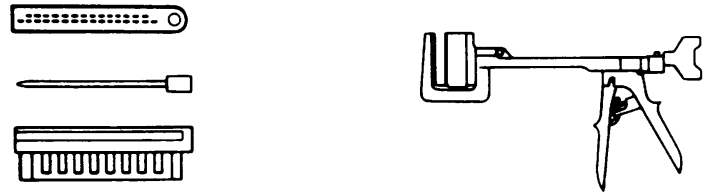

Fig 1 Old style automatic (parallel jaw) stapler TA-55 and disposable loading unit comprising a separate anvil cover, $a$ retaining pin, and a staple cartridge.
Table 2 shows the estimated size and site of the bronchopleural fistula in relation to the bronchial closure line in the two groups. Most of the fistulas in group 2 occurred at one end of the closure line.

Two patients died as a direct result of their fistula. In another patient the fistula contributed to the patient's death three months after the operation. Hence the mortality after development of a fistula was $25 \%$ and this accounts for about half of the mortality in the first three months after pneumonectomy. The remaining nine patients tolerated their fistula well after a drainage procedure, and subsequently had either surgical closure or bronchoscopic cauterisation of the fistula with sodium hydroxide.

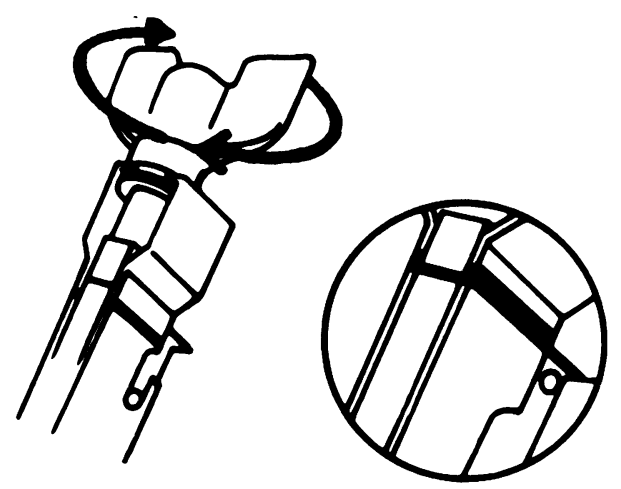

Fig 2 Closure of the TA-55 parallel jaw stapler, achieved by a manually controlled screw thread until the narrow band on the inner frame lies in the confines of the broad band of the outer frame. 

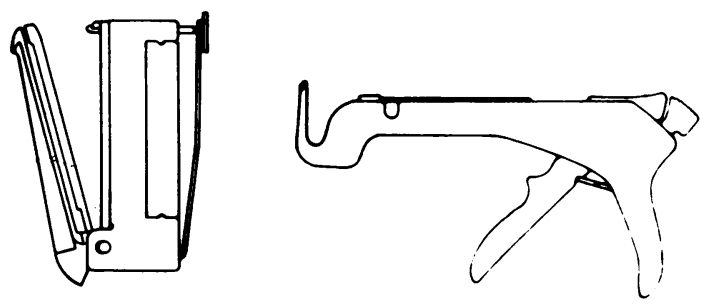

Fig 3 Automatic (hinged jaw) stapler Premium TA-55 and one piece disposable loading unit.

Table 3 compares the group of patients who developed bronchopleural fistulas and those who did not with respect to age, sex, side of operation, type of stapler used, histological type of tumour, disease of mediastinal nodes, and whether the bronchial resection margin was affected by tumour. Each variable was analysed separately with a $\chi^{2}$ test. The variables which achieved significance were the side of operation-the right side being more frequently affected-and the type of stapler used.

The disturbingly higher incidence of bronchopleural fistula associated with the use of the Premium TA stapler than with the old style TA prompted us to investigate the adequacy of bronchial closure and the mechanics of the two staplers.

\section{Tests on staplers}

\section{METHOD}

The two staplers were tested on an unfixed cadaveric right main bronchus, staples of $4.8 \mathrm{~mm}$ leg length being used. The stapled segments of the bronchus were then resected and radiographed en face to show the closed staples.

\section{Results}

We found that with the old style TA stapler the staples were uniformly and completely closed, achieving the final B-shape (fig 4). With the Premium-TA stapler, however, the staples were

Table 2 Size and position of the bronchopleural fistula in the two groups

\begin{tabular}{lll}
\hline & Group 1 & Group 2 \\
\hline Size of bronchopleural fistula & & \\
$<3 \mathrm{~mm}$ & 2 & 6 \\
₹3 mm & 1 & 3 \\
Site of bronchopleural fistula in relation & & \\
to staple line & 0 & 5 \\
End & 1 & 1 \\
Middle & 2 & 3 \\
No comment made & \\
\hline
\end{tabular}

Table 3 Features of patients who did and did not develop a bronchopleural fistula

\begin{tabular}{lcc}
\hline & Fistula & No Fistula \\
\hline Mean age & $62 \cdot 1$ y & $60 \cdot 6 \mathrm{y}$ \\
Sex & 10 & 90 \\
$\quad$ Male & 2 & 28 \\
$\quad$ Female & 10 & 37 \\
Side* & 2 & 81 \\
$\quad$ Right & 3 & 68 \\
$\quad$ Left & 9 & 50 \\
Type of stapler* & & \\
TA-55 & 9 & 92 \\
Premium TA-55 & 3 & 11 \\
Histological type & 0 & 5 \\
$\quad$ Squamous cell carcinoma & 0 & 2 \\
Adenocarcinoma & 0 & 2 \\
Small cell carcinoma & 0 & 6 \\
Large cell carcinoma & \\
$\quad$ Alveolar cell carcinoma & 5 & 39 \\
Others & 7 & 79 \\
Mediastinal nodes & & \\
$\quad$ Nogitive & 0 & 2 \\
Bronchial resection margin affected by & \\
tumour & & \\
\hline
\end{tabular}

${ }^{*}$ Significant difference $\left(\chi^{2}\right.$ test. $\left.\mathrm{p}<0.05\right)$.

only partially closed near the hinge. Closure became more uniform and complete about $10 \mathrm{~mm}$ from the hinge end of the cartridge (fig 5).

The mechanism of closure of the two staplers was carefully examined. The old style TA-55 achieves closure by parallel motion manually controlled by means of a screw thread and by the alignment of two

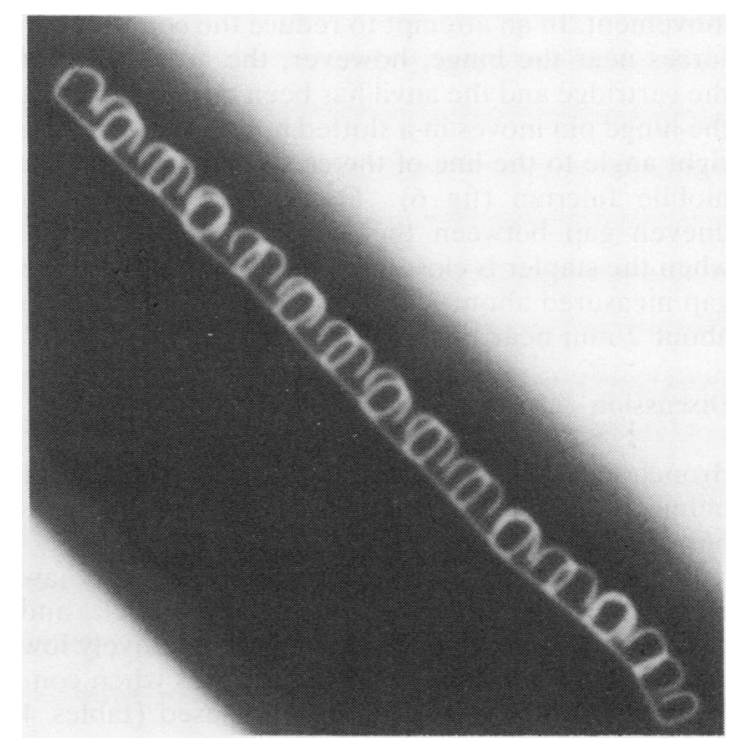

Fig 4 Radiograph of a cadaveric bronchus stapled with the old style TA-55 parallel jaw stapler and $4.8 \mathrm{~mm}$ staples. Note the uniformity of closure of the staples. 


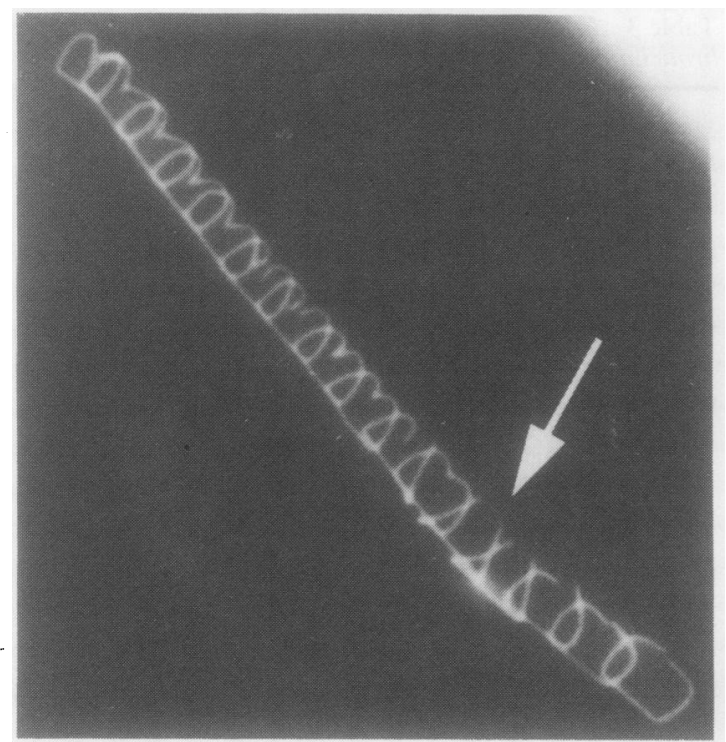

Fig 5 Radiograph of a cadaveric bronchus stapled with the Premium TA-55 hinged jaw stapler and $4.8 \mathrm{~mm}$ staples. The arrow indicates the incomplete closure of staples near the hinge end of the bronchial closure line.

markers engraved on the stapler (fig 2), leaving an even gap about $2 \mathrm{~mm}$ wide between the cartridge and the anvil. The Premium TA-55 on the other hand achieves closure by a toggle mechanism, which is capable of generating large compression forces. The cartridge approximates to the anvil in a hinge movement. In an attempt to reduce the compression forces near the hinge, however, the attachment of the cartridge and the anvil has been designed so that the hinge pin moves in a slotted hole $3 \mathrm{~mm}$ long at a right angle to the line of the cartridge, to produce a mobile fulcrum (fig 6). This has resulted in an uneven gap between the cartridge and the anvil when the stapler is closed around the bronchus. The gap measured about $3 \mathrm{~mm}$ at the hinge, tapering to about $2 \mathrm{~mm}$ near the free end (fig 7).

\section{Discussion}

Bronchopleural fistula is a serious complication of pulmonary resection, with a mortality rate as high as $66.6 \%$.' $^{\prime}$

In most of the reported series using parallel jaw automatic staplers (for example, UKB, UKL, and TA) bronchopleural fistula rates were relatively low and compared favourably with the rates when conventional suturing techniques were used (tables 4 and 5).

Our study confirms that closure of the bronchus with a parallel jaw stapler (TA-55) is uniform and

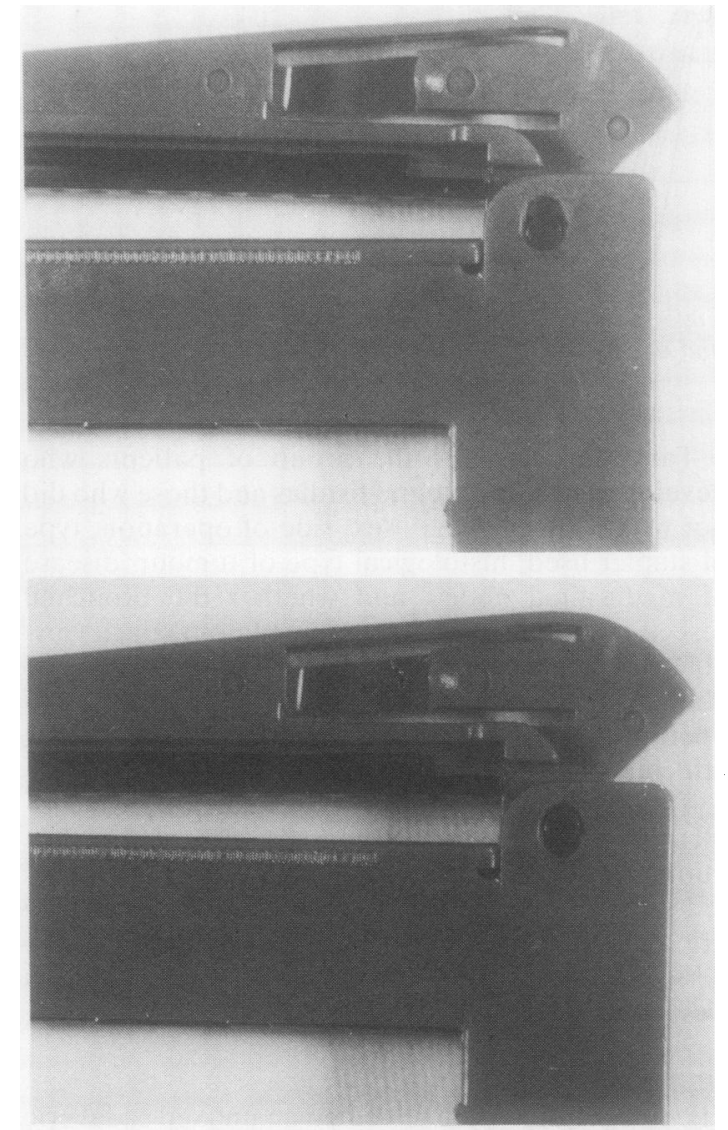

Fig 6 Close up photographs showing movement of the hinge pin during closure of the Premium TA hinged jaw stapler around the bronchus.

independent of the forces applied on firing the staples. In contrast, the hinged jaw stapler (Premium TA-55) produced an uneven closure of the bronchus, which alters according to the force applied in using the stapler, as show by radiographic examination of the staples.

In addition to the non-uniform and incomplete closure of the staples, conceivably the bronchus would be caught in a scissor action if in the early stage of closure of the stapler the hinge pin failed to move in the slot. The subsequent movement of the pin would then allow a distribution of the load in the squashed bronchus, giving the appearance of a parallel action; but the bronchus might then have been severely damaged owing to an excessive load, caused when the pin failed to move initially.

Goldman listed criteria for the evaluation of automatic staplers as compared with standard methods of bronchial closure." The TA-55 stapler 


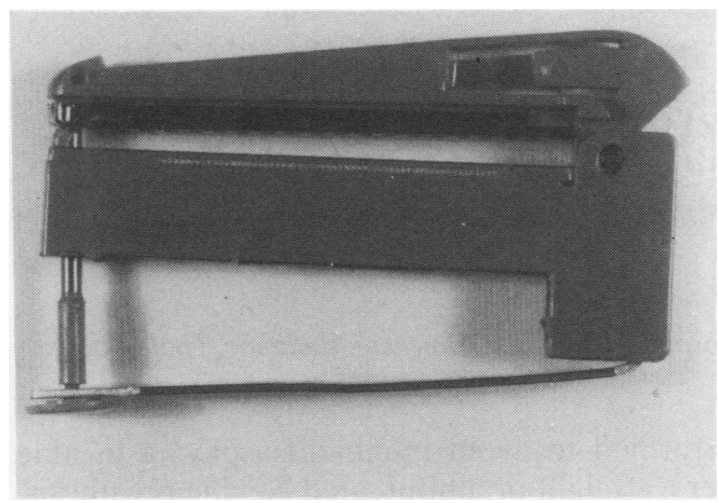

Fig 7 Closure of Premium TA hinged jaw stapler: the gap between the cartridge and the anvil in the final closed position is wider near the hinge.

has fulfilled many of these criteria. It has proved to be consistent in function, safe, and simple to use. The incidence of bronchopleural fistula from major bronchi is lower than with conventional suturing techniques. On the other hand, the Premium TA-55, which has been in use since March 1982, has shown no superiority over the previous model and has been associated in our experience with a significantly higher incidence of bronchopleural fistula.

We conclude that the Premium TA stapler has an inbuilt design weakness, and should be modified before future use in major pulmonary resections.
Table 4 Incidence of bronchopleural fistula after pneumonectomy in published papers

\begin{tabular}{lccc}
\hline Authors & Date & $\begin{array}{l}\text { No of } \\
\text { cases }\end{array}$ & $\begin{array}{l}\text { Incidence of } \\
\text { bronchopleural } \\
\text { fistula (\%) }\end{array}$ \\
\hline Hsin et al & & 1964 & $\begin{array}{l}\text { Not } \\
\text { known }\end{array}$ \\
Williams and Lewis & 27 \\
Forrester-Wood $(225$ cases) & 1980 & 225 & $11 \cdot 1$ \\
\hline
\end{tabular}

\section{References}

1 Bjork VO. Suture material and technique for bronchial closure and bronchial anastomosis. J Thorac Surg 1956;32:22-7.

2 Hsin YL, Hu GP, Chao CW, Chan M. Bronchial stump closure in pulmonary resection. Chin Med J (Peking) 1964;83:89.

3 Williams NS, Lewis CT. Bronchopleural fistula: a review of 86 cases. Br J Surg 1976;63:520-2.

4 Forrester-Wood CP. Bronchopleural fistula following pneumonectomy for carcinoma of the bronchus. Mechanical stapling versus hand suturing. J Thorac Cardiovasc Surg 1980;80:406-9.

5 Ravitch MM, Steichen FM, Fishbein RH, Knowles PW, Weil P. Clinical experiences with the Soviet mechanical bronchus stapler, (UKB-25). J Thorac Cardiovasc Surg 1964;47:446-54.

6 Betts RH, Takaro T. Use of a lung stapler in pulmonary resection. Ann Thorac Surg 1965;1:197-202.

7 Dart CH Jr., Scott SM, Takaro T. Six-year clinical experience using automatic stapling devices for lung resections. Ann Thorac Surg 1970;9:535-50.

8 Hood RM, Kirksey TD, Calhoon JH, Arnold HS, Tate $R$. The use of automatic stapling devices in pulmonary resection. Ann Thorac Surg 1973;16:85-98.

9 Goldman A. An evaluation of automatic suture with UKL-60 and UKL-40 devices by pulmonary resection. Dis Chest 1964;46:29-36.

Table 5 Incidence of bronchopleural fistula after pneumonectomy using different stapling devices

\begin{tabular}{|c|c|c|c|c|}
\hline Authors & Date & Stapler & No of cases & $\begin{array}{l}\text { Incidence of } \\
\text { bronchopleural fistula (\%) }\end{array}$ \\
\hline $\begin{array}{l}\text { Ravitch et } \text { al }^{5} \\
\text { Betts and Takaro } \\
\text { Dart et al } \\
\text { Dart et al } \\
\text { Hood et } a l^{8} \\
\text { Forrester-Wood } \\
\text { Present series } \\
\text { Present series }\end{array}$ & $\begin{array}{l}1963 \\
1965 \\
1970 \\
1970 \\
1973 \\
1980 \\
1984 \\
1984\end{array}$ & $\begin{array}{l}\text { UKB } \\
\text { UKL } \\
\text { UKL } \\
\text { TA } \\
\text { TA } \\
\text { TA } \\
\text { TA } \\
\text { Premium TA }\end{array}$ & $\begin{array}{r}25 \\
40 \\
104 \\
13 \\
60 \\
225 \\
71 \\
59\end{array}$ & $\begin{array}{l}0 \\
5 \\
7 \cdot 7 \\
0 \\
3 \cdot 3 \\
2 \cdot 7 \\
4 \cdot 2 \\
15 \cdot 2\end{array}$ \\
\hline
\end{tabular}

